\title{
DESAIN SISTEM ORDERING SEBAGAI ALAT BANTU PENENTU ANGKA REORDER BERDASARKAN SALES TREND DAN MINIMUM ORDER QUANTITY PADA PERUSAHAAN RETAIL
}

\author{
(Ordering System Design as an Aid to Determine Reorder Scale \\ Based on Sales Trend and Minimum Order Quantity at Retail \\ Company)
}

Nursanti Irliana, Vensy Vydia

Fakultas Teknologi Informasi dan Komunikasi Universitas Semarang

\begin{abstract}
To avoid loss of sales and guarantee the safety stock in a retail company, we need a method to count, and a method when to reorder. There are some methods to count and to decide when a retailer must reorder and how many to be ordered. One of those methods is Reorder Point. Reorder point is a point when the goods must be ordered. After the reorder is calculated, a retailer has to calculate how many unit will be ordered with a right calculation so the good arrival will be on time and appropriate with some terms relate the supplier's conditions, such as minimum order quantity and lead time. Also, must be appropriate with the internal condition, such as last stock quantity and sales trend in a specified period. In line with this condition, the writer will design a system to facilitate the reorder process using a prototype method and visual foxpro programming.
\end{abstract}

Keywords : Reorder point, sales trend, prototype

\section{PENDAHULUAN}

Dalam bisnis ritel, kepuasan pelanggan adalah hal utama untuk menjamin kelangsungan hidup bisnis tesebut. Salah satu faktor yang memuaskan pelanggan adalah stock avaibility, atau ketersediaan stok.

Untuk dapat menjaga ketersediaan barang , retailer membutuhkan sistem perhitungan yang tepat. Berapa jumlah ordernya dan kapan saat mengorder, perlu sebuah metode yang benar. Jangan sampai terlambat mengorder atau kehabisan barang, yang akan mengakibatkan loss of sales atau kehilangan kesempatan menjual.. Juga jangan sampai menyebabkan aging atau over stock, yaitu sebuah kondisi dimana barang sangat berlebih dan melampaui kemampuan retailer untuk menjual. Sehingga bisa dikategorikan barang tidak laku, dan kemudian untuk barang barang yang mempunyai expired date dekat, akan melampaui tanggal kadaluwarsanya. Sehingga yang terjadi adalah barang tersebut akan dimusnahkan atau dibuang. Pada akhirnya menimbulkan shrinkage atau kehilangan dengan nominal yang cukup banyak, yang mengakibatkan kerugian retailer itu sendiri.

Terdapat beberapa metode perhitungan menentukan kapan harus melakukan order. Salah satumya adalah metode Reorder Point.

Reorder Point adalah saat atau titik dimana harus diadakan pesanan lagi sedemikian rupa sehingga kedatangan atau penerimaan barang yang dipesan itu tepat pada waktunya.

Perhitungan Reorder Point (ROP) mengikuti rumusan tertentu yaitu sebagai berikut : 


$$
\text { ROP }=(\text { Lead Time } x \text { Q })+\text { SS }
$$

$Q \quad=$ Penjualan rata - rata per hari

SS = Safety Stock

Lead Time adalah waktu tunggu. Yaitu tenggang waktu yang diperlukan (yang terjadi) antara saat pemesanan barang dengan datangnya barang itu sendiri. Waktu tunggu ini sangat perlu diperhatikan karena sangat mempengaruhi penentuan saat pemesanan kembali (reorder point) Dengan waktu tunggu yang tepat, maka retailer dapat membeli pada saat yang tepat pula. Sehingga resiko kekurangan persediaan barang atau penumpukan persediaan barang, akan ditekan semaksimal mungkin. Bagi retailer, lead time per barang atau per artikel biasanya ditentukan saat pertama kali deal awal pihak buyer (bagian pembelian) dengan supplier. Lead time ini biasanya tidak berubah. Artinya ditentukan sekali, untuk selamanya.

Penjualan rata - rata per hari mengikuti sales trend, yaitu :

Penjualan Rata - rata Per hari = Jumlah unit terjual dalam periode tertentu Jumlah hari dalam periode tersebut

Misal ditetapkan bahwa sales trend yang akan diambil adalah dalam 3 bulan terakhir :

Dua bulan yang lalu (pada bulan tesebut, jumlah hari nya adalah 30 )

Satu bulan yang lalu (pada bulan tersebut, jumlah harinya adalah 31)
Month to Date sales (sales berjalan bulan ini, misal saat ini baru tanggal 15 , berarti penjualan sampai dengan kemarin - tanggal 14)

Maka rata - rata penjualan per hari nya adalah :

\section{Rata - rata pernjualan per hari $=$ Jumlah unit yang terjual dalam 3 bulan ini} $(30+31+14)$

Safety Stock adalah sejumlah persediaan barang yang dicadangkan sebagai pengaman atas kelangsungan transaksi dari sebuah perusahaan retail. Safety Stock diperlukan karena terkadang penjualan tidak selalu mengikuti alur trend penjualan dari periode sebelumnya. Terkadang ada lonjakan permintaan atau pembelian dari pelanggan , sehingga tidak menutup kemungkinan, akhirnya terjadi zero stock. Safety stock ini ditetapkan dengan berbagai metode atau rumusan. Dalam kasus ini, penetapan safety stock yang ada adalah menggunakan metode prosentase. Safety Stock ditetapkan adalah $50 \%$ dari penggunaan selama lead time.

Safety Stock $=50 \% \times$ ( rata-rata penjualan per hari $x$ lead time )

Sehingga didapat rumusan $R e$ Order Point nya adalah :

Reorder Point $=($ Rata-rata penjualan per hari $\mathrm{x}$ lead time $)$ $+50 \%$ (rata-rata penjualan per hari $\mathrm{x}$ lead time)

Setelah mengetahui Reorder Point nya, misalkan pada angka 30. Berarti ketika stok barang tersebut tinggal 30 unit, maka sudah harus dilakukan pemesanan ulang atau reorder. Namun pada kenyataannya, tidak hanya sampai di sini perhitungan reorder.
Pertanyaan berikutnya adalah, berapa jumlah unit yang harus diorder agar cukup untuk kebutuhan penjualan sehingga tidak kehilangan kesempatan menjual namun juga tidak berlebih stoknya ? Dalam hal ini, retailer harus mempertimbangkan Minimum Order 
Quantity yaitu jumlah pemesanan minimum yang dipersyaratkan oleh supplier (pemasok). Misalnya Reorder Point nya adalah 30 , dan stok saat ini sudah mencapai angka 30 . Kemudian retailer ingin mengorder, namun Minimum Order Quantity yang dipersyaratkan oleh supplier adala 12. Maka order yang dibuat harus mengikuti kelipatan 12 . Jadi order harus dibulatkan menjadi 36.

Hal lain yang menjadi pertimbangan dalam melakukan order adalah Sales Historical atau Sales Trend, yaitu penjualan dalam periode tertentu, seperti yang telah dicontohkan di atas, yaitu tiga bulan. Ketika posisi stok sudah mencapai titik harus diorder, maka tidak bijak jika langsung menetapkan order ke supplier. Sebaiknya meninjau terlebih dahulu, apakah Sales Trend nya bagus dalam kurun tiga bulan terakhir. Atau apakah tidak ada penjualan dalam tiga bulan tersebut, kemudian saat ini posisi stok adalah kosong, karena kemudian barang telah expired dan di buang ? Apabila kondisinya demikian, maka yan harus dilakukan adalah membuat keputusan, apakah akan tetap diorder sesuai minimum order quantity saja, dengan memperbaiki promosinya, displaynya (peletakan dan penataan barang di rak), dan informasi mengani barang tersebut. Atau apakah kemudian diputuskan untuk tidak perlu mengorder sama sekali, karena barang tersebut tidak laku dan tidak ada pelanggan yang berminat.

Kemudian, retiailer juga harus mempertimbangkan lead time,yaitu waktu pengiriman supplier. Agar barang yang diorder tepat waktu kedatangannya.

Dari segala kekompleksan reorder ini, dibutuhkan sebuah sistem yang bisa menangani perhitungannya. Sehingga proses reordering bisa dilakukan dengan lebih mudah dan cepat. Pemograman visual dipilih karena lebih dikenal oleh pengguna.

Pendekatan pengembangan sistem menggunakan pendekatan prototype, dimana terdapat peran dari pengguna untuk memberikan masukan atas sistem yang dibuat. Dengan metode ini, pengguna mendapatkan gambaran awal dari sistem kemudian memberikan masukan apakah sistem telah sesuai. Kemudian sistem diperbaiki sampai sesuai dengan kebutuhan dan kondisi pengguna.

\section{ANALISA KEBUTUHAN SISTEM}

Dalam pengembangan sistem ini, dibutuhkan hardware dan software pendukung yang sesuai dengan kebutuhan sistem dan kemampuan user.

$\begin{array}{ll}\begin{array}{l}\text { Hardware } \\ \text { Monitor }\end{array} & \text { : AOC e1620Sw } \\ \text { Processor } & : \text { INTEL Core i3 550 } \\ \text { RAM } & : 4 \text { GB } \\ \text { Hard Disk } & : 500 \text { GB } \\ \text { Power Supply } & : \text { ANTEC VP-450 } \\ \text { Keyboard } & : \text { Standard } \\ \text { Mouse } & : \text { Standard Optical } \\ \text { Mouse } & \end{array}$

\section{Software}

Aplikasi ini dibangun dengan menggunakan software Microsoft Visual Foxpro 9.0. Untuk sistem operasinya menggunakan Sistem Operasi Windows XP.

\section{METODE PENGEMBANGAN SISTEM}

Metode pengembangan sistem yang digunakan dalam proyek ini adalah model Prototype. Model prototype adalah proses dimana permintaan pengguna diubah ke dalam sistem yang bekerja, secara terus menerus diperbaiki melalui kerja sama antara pengguna dan pembuat sistem.

Metode ini sering digunakan dalam pengembangan sistem,karena terdapat interaksi yang baik antara pengguna dan pembuat sistem.

Sering terjadi gap antara pengguna dan pembuat sistem. Dimana pengguna hanya mendefinisikan secara umum apa saja yang dikehendakinya tanpa menyebutkan secara detail, output apa yang dibutuhkan, pemrosesan dan data apa saja yang dibutuhkan, kendala lapangan, dan lain sebagianya. Dan sebaliknya, dari sisi pembuat 
sistem, kurang memperhatikan kondisi kemampuan pengguna, kondisi lapangan, dan kebutuhan pengguna secara detail.

Dengan menggunakan model prototype, pengguna dilibatkan secara aktif dalam proses pengembangan sistem.

Adapun tahap - tahap dalam model prototype ini adalah sebagai berikut :

1. Identifikasi kebutuhan

Pembuat sistem, bersama sama dengan pengguna mendifinisikan format seluruh perangkat lunak, mengidentifikasikan seluruh kebutuhan, dan garis besar sistem yang akan dibuat.

2. Membangun prototyping

Adalah proses pembuatan rancangan sementara yang berfokus pada penyajian kepada pelanggan. Contohnya adalah desain form input dan format output atau laporannya.

3. Evaluasi prototyping

Langkah ini melibatkan pengguna. Dimana pengguna akan memberikan penilaian, apakah prototype nya sudah sesuai dengan kebutuhan dan keinginan pelanggan. Jika sudah, maka pembuat sistem akan melanjutkan ke langkah berikutnya. Jika belum, maka akan diulang dari langkah 1,2 dan 3.

\section{Coding}

Pada tahap ini, setelah semua desain sesuai dengan kebutuhan pengguna, maka akan diterjemahkan ke dalam bahasa pemrograman yang akan dipakai dalam sistem.

5. Menguji Sistem dan Evaluasi

Setelah program bantu jadi, maka diujicobakan pada sistem. Dan diamati apakah sudah sesuai dan sudah dapat mengatasi kebutuhan serta kendala lapangan. Uij coba ini menjadi evaluasi bersama antara pengguna dan pembuat sistem. Jika dirasa masih ada yan kurang sesuai, maka akan diulang dari langkah ke 4. Jika sudah cocok, dilanjutkan dengan tahap ke 6 .

6. Implementasi Sistem

Program bantu yang sudah jadi dan diterima oleh pengguna, siap diimplementasikan.

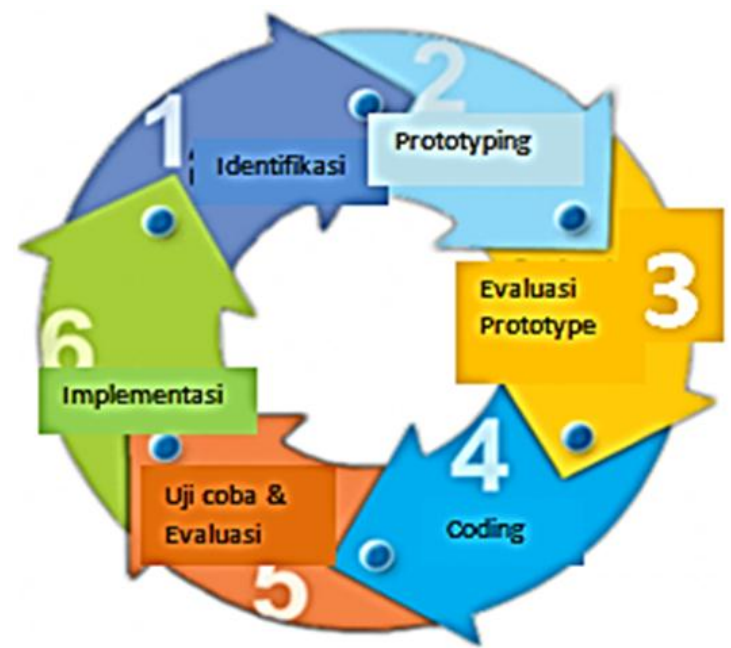

Gambar 1. Model Prototype

4. HASIL DAN PEMBAHASAN

4.1. Perancangan Sistem Reorder Point berdasarkan Sales Trend

Desain sistem ini menggunakan Use Case

Diagram untuk merepresentasikan sebuah interaksi antara pengguna dan sistem. Use Case Diagram digunakan untuk mengetahui fungsi apa saja yang ada dalam sebuah sistem dan siapa saja yang berhak menggunakan fungsi - fungsi tersebut. Selain Use Case Diagram, penulis juga merepresentasikan proses dalam Activity Diagram, Sequence Diagram dan Class Diagram.

Sistem dalam sebuah perusahaan retail dapat digambarkan dalam Gambar 2. Dimana proses dimulai dari ordering atau pemesanan 
barang, kemudian good receiving atau proses penjualan. Proses kemudian akan kembali ke kedatangan barang dan terakhir adalah ordering lagi.

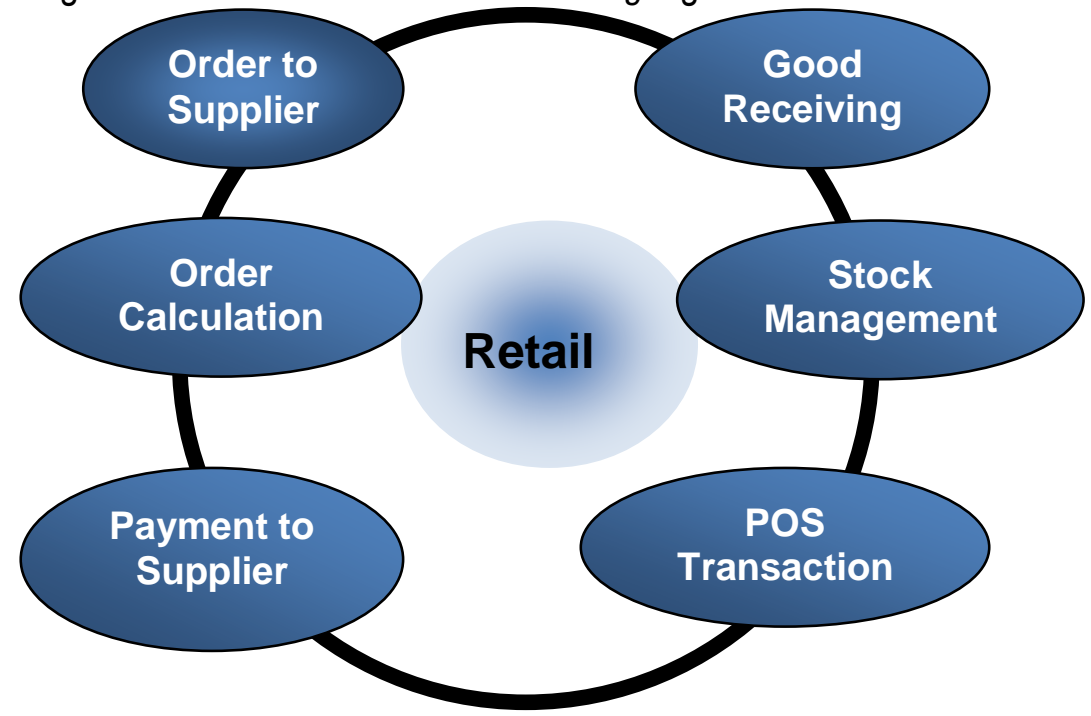

Gambar 2. Proses dalam bisnis retail

Dalam hal ini, penulis berfokus pada proses persiapan ordering (order calculation) . Dan pengguna sistem adalah seorang petugas ordering, yaitu petugas yang mengurus administrasi reorder kepada supplier. Dimana detailnya dapat diilustrasikan sebagai berikut :

1. Petugas ordering mengambil data dari sistem penerimaan barang dan penjualan barang. Adapun Data yang diambil adalah :

a. Data Artikel atau barang

b. Data Supplier

c. Data Kasir

d. Data Customer (pelanggan)

Ketiga data di atas cukup sekali ambil dan disimpan dalam sistem. Karena data - data ini relatif tetap dan tidak mengalami perubahan dalam jangka waktu panjang.

Data lain adalah :

a. Data transaksi Point Of Sales (transaksi penjualan), dalam kurun 3 bulan terakhir.

b. Data transaksi Good Receiving(kedatangan barang)

Kedua data ini harus diupdate harian. Dimana proses updatingi harus dilakukan oleh petugas ordering tiap pagi.

1. Petugas ordering mencetak Order Proposal List

Order Proposal List adalah daftar pesanan per barang yang merupakan hasil perhitungan
Reorder Point dengan memperhatikan Minimum Order Quantity dan Sales Trend barang tersebut. Dalam Order Proposal List ini telah tercantum angka yang harus diorder, per barang. Jika ada revisi atas angka tersebut, misalkan akan ditambah karena saat ini kondisi peak seasson (hari raya, atau liburan ), dimana barang tersebut akan sangat diminati oleh pelanggan, maka harus mendapatkan persetujuan pimpinan toko terlebih dahulu.

2. Petugas ordering menginput revisi Order Proposal List jika ada.

Jika ada revisi seperti yang telah disebutkan di atas, maka petugas ordering akan menginput pada menu Revisi Order. Maka angka atau jumlah barang yang akan diorder berikutnya, akan diganti. Sehingga saat mngkonfirmasikan pesanan kepada supplier, sudah tidak mengikuti angka dalam Order Proposal List.

3. Petugas mencetak Order Sheet yang akan diteruskan (difax atau disampaikan langsung) kepada supplier. Order Sheet ini berisi nama barang dan jumlah barang yang akan dipesan kepada supplier. Dicetak per supplier dan dikonfirmasikan melalui faks atau disampaikan langsung saat supplier mengunjungi toko retailer. 
4. Jika tidak ada revisi atas Order Proposal Dari ilustrasi di atas, maka Use Case List, maka petugas ordering akan langsung Diagramnya adalah pada Gambar 3 sebagai mencetak Order Sheet.

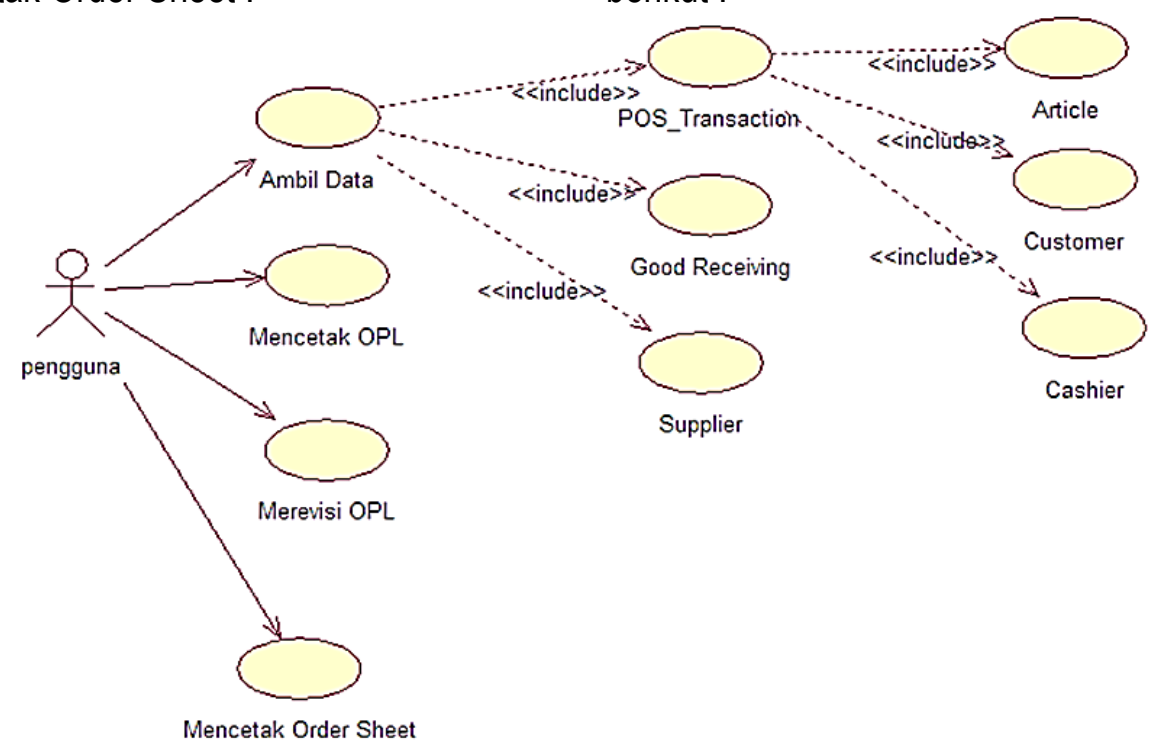

Gambar 3. Use Case Diagram Sistem Reorder Point Berdasarkan Sales Trend

Aliran kerja (workflow) seperti pada ilustrasi di atas dapat digambarkan pada Gambar 4, yaitu Activity Diagram.

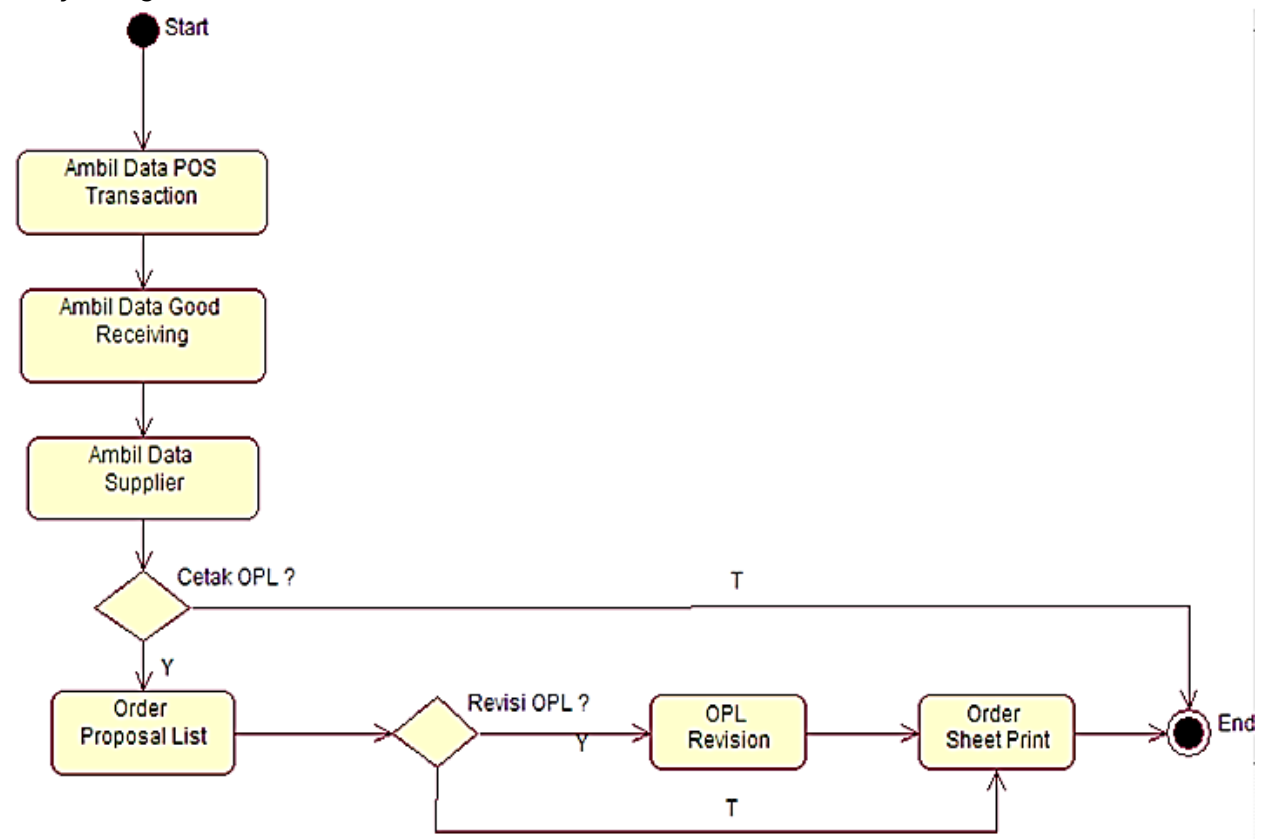

Gambar 4. Acitivity Diagram Sistem Reorder Point Berdasarkan Sales Trend

Sequence Diagram menggambarkan objek.Sequence Diagram menunjukkan perilaku objek pada use case dengan komunikasi antara satu menu dengan menu mendeskripsikan waktu hidup objek dan lainnya. Komunikasi dan interaksi dalam message yang dikirimkan dan diterima antar sistem ini ditunjukkan pada Gambar 5. 


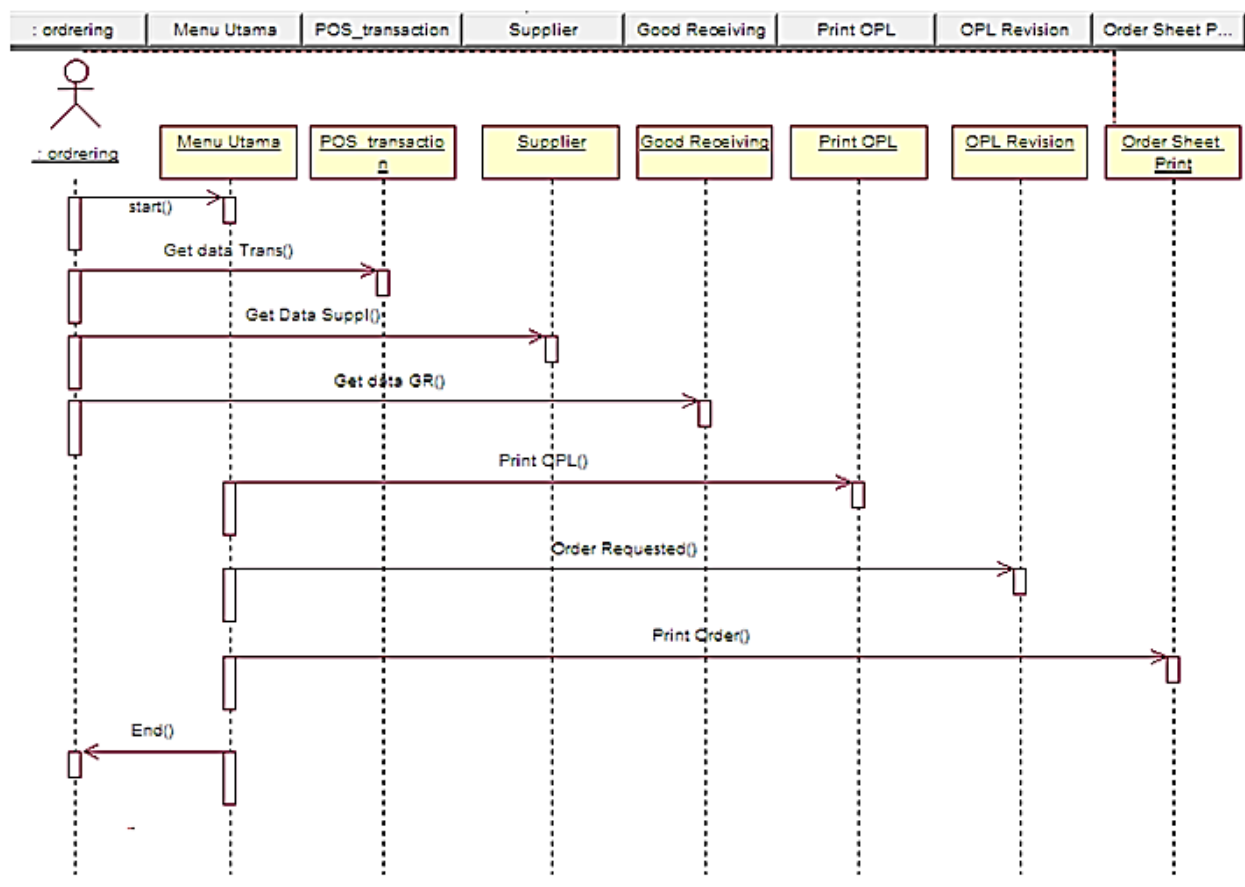

Gambar 5. Sequence Diagram Sistem Reorder Point Berdasarkan Sales Trend

Class Diagram sangat membantu dalam masing class.Dalam sistem ini, class visualisasi struktur kelas dari suatu sistem. diagramnya adalah seperti dalam Gambar 6 .

Berisi atribut - atribut dan relasi atas masing

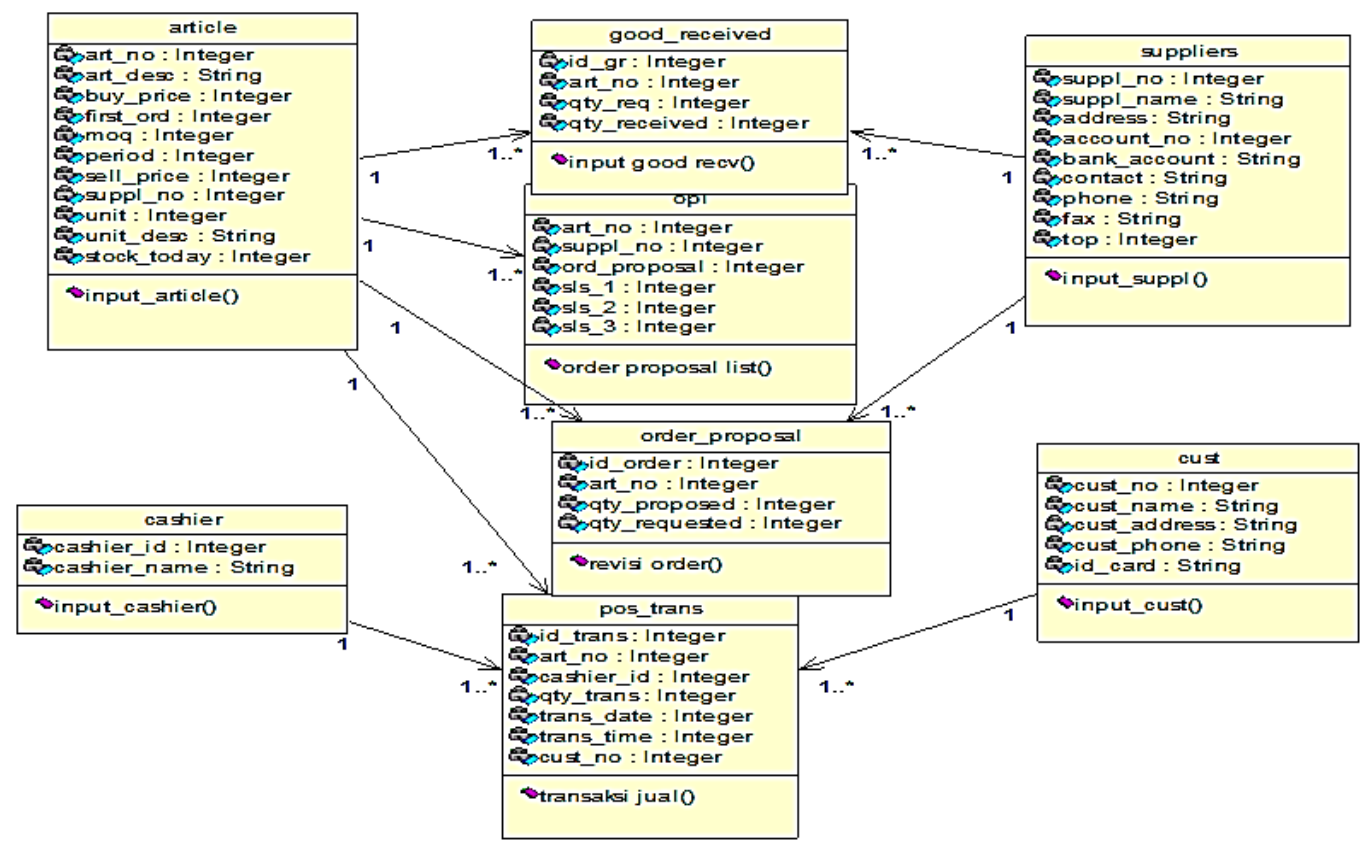

Gambar 6. Class Diagram Sistem Reorder Point Berdasarkan Sales Trend

4.2. Studi Kasus dan Pemecahan Masalah Setelah petugas ordering mengambil data artikel supplier, kasir, customer, POS transaction dan Good Receiving, maka proses yang akan berjalan adalah : 
1. Mencetak Order Proposal List (OPL) , dimana petugas tersebut akan mengakses menu "Print OPL" untuk mencetak Order Proposal List seperti dalam Gambar 7.

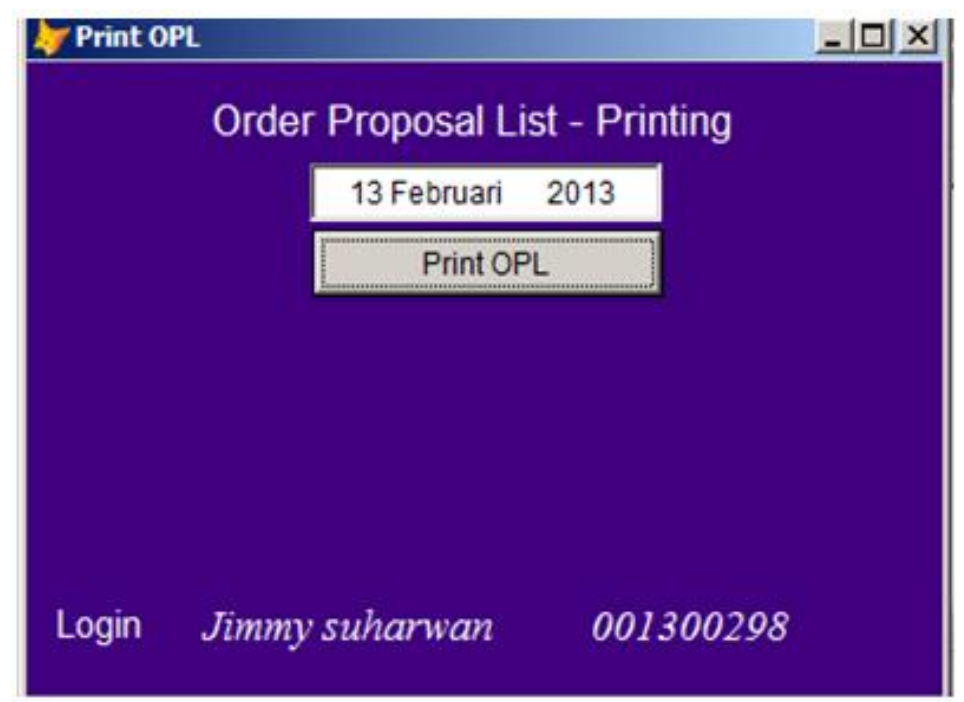

Gambar 7. Form Print OPL

Kemudian proses dalam sistem, dapat diuraikan sebagai berikut :

a. Sistem akan menghitung Reorder Point (ROP) masing - masing artikel.

b. Artikel yang stok nya sama atau di bawah ROP , akan terdaftar sebagai artikel yang akan tampil dalam OPL.

c. Sistem kemudian akan menghitung angka order (berapa unit harus diorder) dengan mempertimbangkan Minimum Order Quantity (MoQ) , Lead Time dan Sales Trend.

Perhitungannya mengikuti rumusan sebagai berikut :

Lihat posisi Stock Today (stok saat ini).

- Jika Stok < ROP

- Lihat MOQ, Lead Time dan Rata rata penjualan per hari

- Jika rata-rata < Stock Today

- Lihat Lead Time

- Jika Stok Today $>=$ (rata-rata $\mathrm{x}$ lead time)

Order $=0$
- Jika Stok Today< (rata-rata $\mathrm{x}$ lead time) Jika (rata-rata $x$ lead time) $<\mathrm{MOQ}$ Order $=\mathrm{MOQ}$

Jika (rata-rata $x$ lead time) $>=$ $\mathrm{MOQ}$

Order=rata-rata $x$ lead time

- Jika rata-rata >= Stock Today

Order $=$ (rata-rata $\times$ lead time) stock today

- Jika Stok >= ROP

- Jika (rata-rata $\mathrm{x}$ lead time ) $<=$ stock today

Order $=0$

- Jika (rata-rata $x$ lead time ) > stock today

Order $=($ rata-rata $\times$ lead time $) \times M O Q$ $\mathrm{MOQ}$

Seluruh angka mengikuti pembulatan ke atas untuk menyesuakan $\mathrm{MOQ}$.

Contoh kasus, Terdapat data barang sebagai berikut : 
Tabel 1. Contoh Kasus : Data Barang

\begin{tabular}{|c|c|c|c|c|c|c|c|c|c|}
\hline \multirow{2}{*}{$\begin{array}{c}\text { Article } \\
\text { No }\end{array}$} & \multirow{2}{*}{ Article Description } & \multirow{2}{*}{$\begin{array}{l}\text { Lead } \\
\text { Time }\end{array}$} & \multirow{2}{*}{ MOQ } & \multicolumn{3}{|c|}{ Sales } & \multirow{2}{*}{ ROP } & \multirow{2}{*}{$\begin{array}{l}\text { Stock } \\
\text { Today }\end{array}$} & \multirow{2}{*}{ Keterangan } \\
\hline & & & & Bln 1 & $B \ln 2$ & $B \ln 3$ & & & \\
\hline 314433 & Kecap Mirama Per Botol & 4 & 12 & 75 & 200 & 185 & 9 & & Barang Laku, Stock > $>$ ROP \\
\hline 547866 & Indomie Grg Per Pcs & 2 & 24 & 65 & 35 & 60 & 3 & & 2 Barang Laku, Stock <ROP \\
\hline 231445 & Coca Cola Pet 1000 L Per Botol & 1 & 12 & 0 & 3 & 8 & 0 & & 2 Tidak laku, Stock > ROP \\
\hline 547784 & Indomie Kaldu Spec Per Pcs & 6 & 24 & 40 & 42 & 16 & 2 & & Barang Laku, Stock < ROP \\
\hline
\end{tabular}

Contoh perhitungan ROP untuk barang no 1, Article No 314433 Kecap Mirama Per botol. Misal Bulan 1 jumlah hari nya 30 . Bulan 2 jumlah hari nya 31 . Dan bulan 3 yaitu bulan berjalan saat ini, sudah tanggal 15 . Berarti sales nya sampai dengan hari kemarin, tanggal 14 .

ROP

$=($ Rata - rata penjualan per hari $x$ lead time $)$

$+50 \%($ Rata - rata penjualan per hari $x$ lead time $)$

$R O P=\left(\frac{(75+200+185) x 3}{(30+31+14)}\right)+50 \%\left(\frac{(75+200+185) \times 3}{(30+31+14)}\right)$ $R O P=9$
Dengan stok 30 ,yaitu di atas ROP , , dan $M O Q$ adalah 12 hari dan (rata-rata penjualan per hari $\mathrm{x}$ lead time) $=25$ (di bawah stok, masih cukup selama lead time), maka perhitungan ordernya sesuai dengan cara hitung di atas adalah:

Order $=0$

Barang yang tercetak di OPL hanya barang yang perhitungan ordernya $>0$. Setelah proses perhitungan sistem ini selesai, maka akan OPL akan tercetak. Bentuk OPL adalah sebagaimana dalam Gambar 8.

\begin{tabular}{|c|c|c|c|c|c|c|c|c|c|c|c|c|}
\hline \multicolumn{13}{|c|}{$\begin{array}{l}\text { Order Proposal List - Today } \\
15 / 02 / 13\end{array}$} \\
\hline No Suppl Artide No & Article Description & Lead Time & MOQ & ROP & Rata2 Penj & \multicolumn{3}{|c|}{\begin{tabular}{|c|} 
Sales Trend \\
SIs M1| SIs M2 SIs M3
\end{tabular}} & \begin{tabular}{|l|} 
Stock \\
Today
\end{tabular} & \begin{tabular}{|l|} 
Ord \\
Proposal
\end{tabular} & \begin{tabular}{|l|} 
Ord \\
Request
\end{tabular} & $\mathrm{PF}$ \\
\hline 2134 & \multicolumn{12}{|l|}{ PT INTRA MEGAH } \\
\hline 314433 & KECAP MIRAMAPER BOTOL & 4 & 12 & 9 & 6 & 75 & 200 & 185 & 30 & 24 & & \\
\hline 3467 & \multicolumn{12}{|l|}{ INDOFOOD } \\
\hline 547784 & INDOMIE KALDU SPEC PER PCS & 6 & 24 & 2 & 1 & 65 & 35 & 60 & 2 & 24 & & \\
\hline 547866 & INDOMIE GRG PER PCS & 2 & 24 & 3 & 2 & 40 & 42 & 16 & 1 & 12 & & \\
\hline
\end{tabular}

Gambar 8. Order Proposal List

2. Melakukan revisi OPL dalam sistem, dengan mengakses menu "Revisi OPL" seperti dalam Gambar 9.

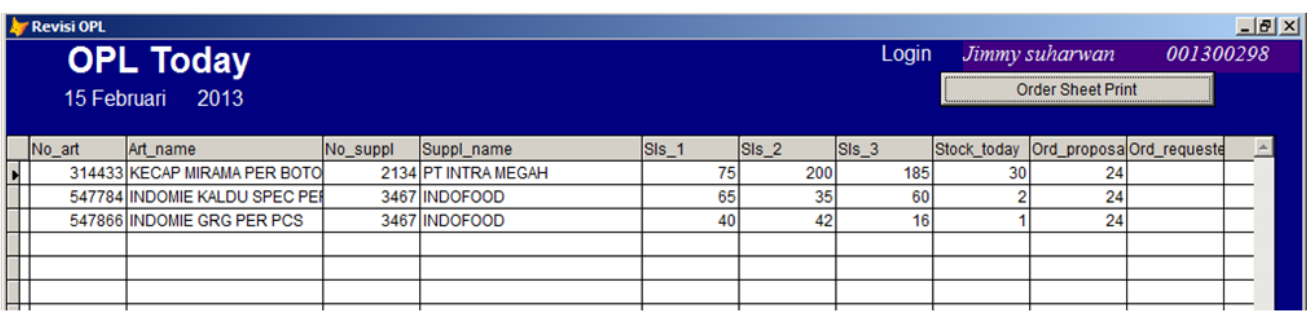

Gambar 9. Menu Revisi OPL

Petugas menginput revisi angka order di revisi ini, data otomatis tersimpan ke dalam bagian "Ord_requested". Setelah menginput sistem. 
3. Mencetak Order Sheet dengan gambar 9. Dan akan tampil tercetak mengklik tombol "Order Sheet Print" pada menu "Revisi OPL" dalam

\begin{tabular}{|c|c|c|}
\hline \multicolumn{2}{|c|}{ ORDER SHEET TO SUPPLIER } & No. Order : 00120213 \\
\hline \multirow{2}{*}{\multicolumn{3}{|c|}{$\begin{array}{l}\text { Kepada } \\
\text { Yth. Supplier }\end{array}$}} \\
\hline & & \\
\hline \multirow{2}{*}{\multicolumn{3}{|c|}{$\begin{array}{l}2134 \text { PT INTRA MEGAH } \\
\text { di Semarang }\end{array}$}} \\
\hline & & \\
\hline \multicolumn{3}{|c|}{ Mohon dikirim kepada kami barang - barang sebagaimana tercantum dalam daftar berikut : } \\
\hline No Artikel & Deskripsi Artikel & Jumlah Unit \\
\hline 314433 & KECAP MIRAMA PER BOTOL & 24 \\
\hline \multicolumn{3}{|c|}{ Mohon konfirmas i bila barang yang termaksud di atas tidak bis a dikirim / mengalami penundaan kirim } \\
\hline
\end{tabular}

\section{Gambar 10. Order Sheet}

\subsection{Pengujian}

Dari hasil pengujian yang dilakukan, dengan contoh data seperti tercantum dalam Tabel 1, ditemukan bahwa perhitungan order yang dilakukan sistem, telah sesuai dengan perhitungan secara manual. Pengujian pertama adalah mengecek data artikel/barang yang tercantum dalam Tabel 1. Baik data MoQ atauun Lead Timenya dari menu "Article Information" seperti dalam Gambar 11.

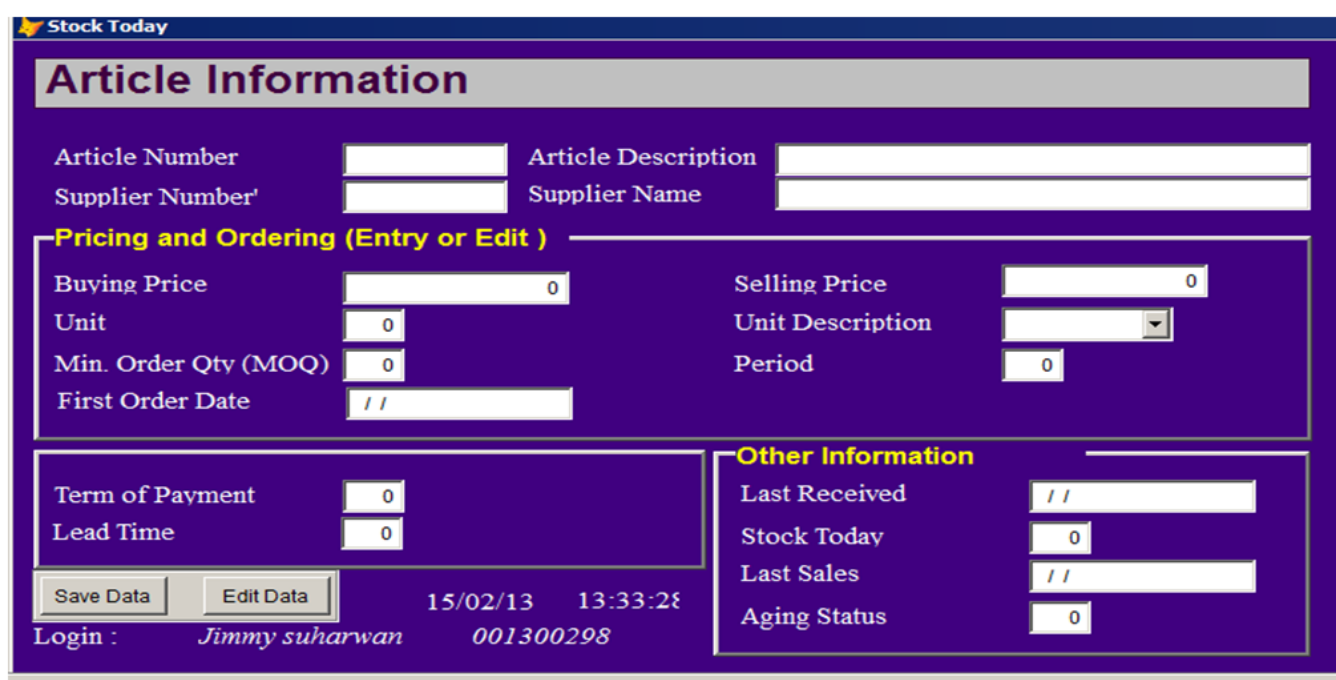

Gambar 11. Menu Article Information

Perhitungan ROP dan angka Order, perhitungan sistem dan perhitungan manual menunjukkan hasil yang sama antara seperti yang tampak pada Tabel 2. 
Tabel 2. Perbandingan Pengujian Sistem

\begin{tabular}{l|l|c|c|c|c|}
\hline \multirow{2}{*}{$\begin{array}{c}\text { Article } \\
\text { No }\end{array}$} & \multirow{2}{*}{ Article Description } & \multicolumn{3}{|c|}{ Perhitungan Sistem } & \multicolumn{2}{|c|}{ Perhitungan Manual } \\
\cline { 3 - 6 } & & ROP & Order & ROP & Order \\
\hline 314433 & Kecap Mirama Per Botol & 9 & 24 & 9 & 24 \\
\hline 547866 & Indomie Grg Per Pcs & 3 & 12 & 3 & 12 \\
\hline 231445 & Coca Cola Pet 1000 L Per Botol & 0 & 0 & 0 & 0 \\
\hline 547784 & Indomie Kaldu Spec Per Pcs & 2 & 24 & 2 & 24 \\
\hline
\end{tabular}

Kemudian pada Order Proposal List, artikel tersebut tidak akan tercetak pada OPL, karena artikel "Coca Cola Pet 1000 L Per seperti terdapat pada Gambar 12.

Botol" mempunyai angka order $=0$, maka

\begin{tabular}{|c|c|c|c|c|c|c|c|c|c|c|c|c|}
\hline \multicolumn{13}{|c|}{$\begin{array}{l}\text { Order Proposal List - Today } \\
\text { 15/02/13 }\end{array}$} \\
\hline No Suppl Artide No & Article Description & Lead Time & MOQ & ROP & Rata2 Penj & \multicolumn{3}{|c|}{\begin{tabular}{|c|}
\multicolumn{2}{|c|}{ Sales Trend } \\
SIs M1| SIs M2 SIs M3 \\
\end{tabular}} & \begin{tabular}{|l|} 
Stock \\
Today
\end{tabular} & \begin{tabular}{|c|} 
Ord \\
Proposal
\end{tabular} & \begin{tabular}{|c|} 
Ord \\
Request
\end{tabular} & $\overline{\mathrm{PF}}$ \\
\hline 2134 & \multicolumn{12}{|l|}{ PT INTRA MEGAH } \\
\hline 314433 & KECAP MIRAMAPER BOTOL & 4 & 12 & 9 & 6 & 75 & 200 & 185 & 30 & 24 & & \\
\hline \multicolumn{13}{|c|}{ INDOFOOD } \\
\hline 547784 & INDOMIE KALDU SPEC PER PCS & 6 & 24 & 2 & 1 & 65 & 35 & 60 & 2 & 24 & & \\
\hline 547866 & INDOMIE GRG PER RCS & 2 & 24 & 3 & 2 & 40 & 42 & 16 & 1 & 12 & & \\
\hline
\end{tabular}

Gambar 12. Order Proposal List, hanya artikel yang angka order proposalnya $>0$

Jika dicoba untuk melakukan revisi angka menu "Revisi OPL" pada Gambar 13 di bawah order dengan mengisi "Order requested" pada ini

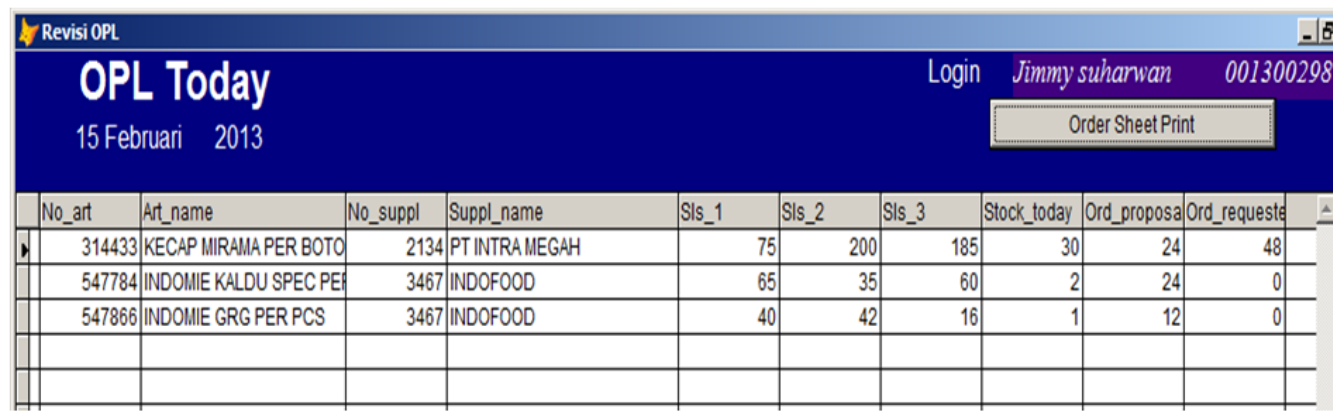

Gambar 13 Revisi OPL di artikel "Kecap Mirama Per Botol"

Revisi dilakukan untuk angka order pada artikel "Kecap Mirama Per Botol", dimana angka awalnya adalah 24 , kemudian diganti menjadi 48. Maka Order Sheet nya akan berubah pula, angka order nya adalah 48, sebagaimana yang ditunjukkan pada Gambar 14. 


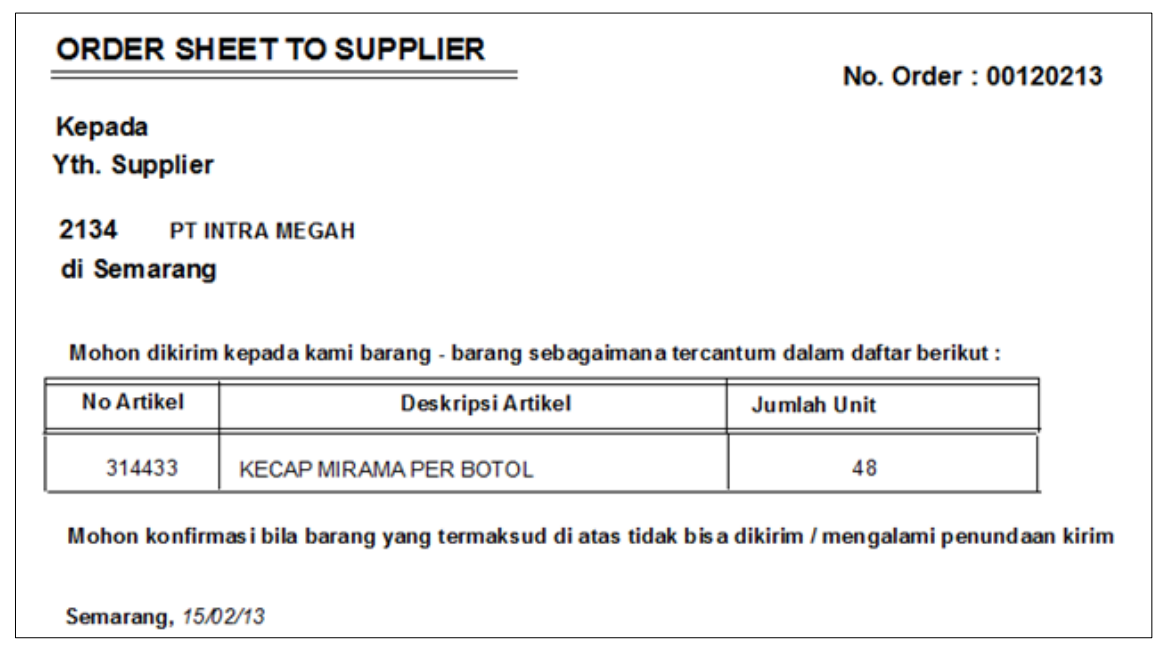

Gambar 14. Order Sheet setelah angka order direvisi

Untuk artikel yang tidak mengalami perubahan angka order, maka secara otomatis , sistem akan mengisi "Order Requested" nya sama dengan angka "Order Proposal".

\section{KESIMPULAN}

Angka Reoder harus diperhitungkan dengan sebaik - baiknya dalam menjamin ketersediaan stok barang dalam perusahaan retail. Perhitungan ini selain mempertimbangkan Sales Trend, juga harus memperhitungkan Lead Time, Minimum Order Quantity dan Reorder Point.

Dalam perancangan ini, telah diujicobakan perhitungan manual dan perhitungan secara sistem, yang menunjukkan hasil yang sama. Telah diujicobakan pula jika ada perubahan angka order, otomatis angka yang tercetak dalam Order Sheet akan terubah pula Sehingga proses perhitungan angka reorder akan lebih cepat, tepat dan mudah.

Metode Prototype tepat dipilih dalam pengembangan sistem ini, karena pengguna dapat berperan aktif dalam perancangan sistem ini.

\section{DAFTAR PUSTAKA}

Adhian Agung Yulianto,2009, Analisis dan Desain Sistem Informasi, Politeknik Telkom Bandung,

Asep ST Sujana, 2012, Manajemen Minimarket, Raih Asa Sukses ( Penebar Swadaya Group )

Deddy Kusbianto, 2010, Analisis Dan Perancangan Sistem Informasi, STMIK Yadika Bangil

Djajakusuma Tjahjadi, 2004, Mengelola data dengan Visual Foxpro 8.0, Penerbit ANDI Yogyakarta

$h t t p: / / w w w$.

christkaizen.files.wordpress.com/2011/0 3/eoq2.doc diakses 30 Januari 2013

MADCOMS, 2006, Aplikasi Program Database Inventory Dengan Microsoft Visual Foxpro,Penerbit ANDI Yogyakarta

Munawar, 2005, Pemodelan Visual dengan UML, Graha IImu

Sigit Triyono, 2006, Sukses Terpadu Bisnis Ritel Dari Merchandising sampai Shrinkage, PT Gramedia Jakarta

http://christkaizen.com/2011/02/28/penentuansafety-stock.doc diakses 11 Februari 2013

http://fst.uty.ac.id/elearning/claroline/backends/ download.php/manajemen-

persediaan.ppt diakses 30 Januari 2013 